\title{
Developmental ORIgins of Healthy and Unhealthy AgeiNg: The Role of Maternal Obesity - Introduction to DORIAN
}

\author{
Patricia Iozzo ${ }^{a}$ Megan Holmes ${ }^{c}$ Mathias V. Schmidt ${ }^{d}$ Francesca Cirulli $^{b}$ \\ Maria Angela Guzzardia Alessandra Berry ${ }^{b}$ Georgia Balsevich ${ }^{d}$ \\ Maria Grazia Andreassi ${ }^{a} \quad$ Jan-Jaap Wesselink ${ }^{\mathrm{e}}$ Tiziana Liistro $^{a}$ \\ Paulino Gómez-Puertas ${ }^{\mathrm{e}} \quad$ Johan G. Eriksson ${ }^{\mathrm{f} g}$ Jonathan Seckl ${ }^{\mathrm{c}}$ \\ ${ }^{a}$ Institute of Clinical Physiology, National Research Council (CNR), Pisa, ${ }^{b}$ Istituto Superiore \\ di Sanità (ISS), Rome, Italy, 'Cndocrinology Unit, Centre for Cardiovascular Science, \\ University of Edinburgh, Edinburgh, UK, d Max-Planck-Institute of Psychiatry (MPG), Munich, \\ Germany, ${ }^{e}$ biomol-informatics SL, Madrid, Spain, ${ }^{\dagger}$ Samfundet Folkhälsan i Svenska Finland \\ rf (Folkhälsan), ${ }^{9}$ Department of General Practice and Primary Health Care, University of \\ Helsinki, Helsinki, Finland
}

\section{Key Words}

Pregnancy · Foetal programming · Obesity · Diabetes · Cardiovascular disease - Stress .

Oxidative damage $\cdot$ Insulin resistance $\cdot$ HSD2 $\cdot$ p66

\begin{abstract}
Europe has the highest proportion of elderly people in the world. Cardiovascular disease, type 2 diabetes, sarcopenia and cognitive decline frequently coexist in the same aged individual, sharing common early risk factors and being mutually reinforcing. Among conditions which may contribute to establish early risk factors, this review focuses on maternal obesity, since the epidemic of obesity involves an ever growing number of women of reproductive age and children, calling for appropriate studies to understand the consequences of maternal obesity on the offspring's health and for developing effective measures and policies to improve people's health before their conception and birth. Though the current knowledge suggests that the long-term impact of maternal obesity on the offspring's health may be substantial, the outcomes of maternal obesity over the lifespan have not been quantified, and the molecular changes induced by maternal obesity remain poorly characterized. We hypothesize that maternal insulin resistance and reduced placental glucocorticoid catabolism, leading to oxidative stress, may damage the DNA, either in its structure (telomere shortening) or in its function (via epigenetic changes), resulting in altered gene expression/repair, disease during life, and pathological ageing. This review illustrates the background to the EU-FP7-HEALTH-DORIAN project.


Iozzo et al.: Developmental ORIgins of Healthy and Unhealthy AgeiNg: The Role of Maternal Obesity - Introduction to DORIAN

\section{Introduction}

Obesity has reached epidemic proportions and is the main health as well as social concern in the developed world and, increasingly, in developing countries. In the EU, one third of women of reproductive age are overweight and $20 \%$ are obese. This prevalence is expected to almost double in the next decade [1]. Maternal obesity is associated with adverse acute maternal and neonatal outcomes, and the long-term consequences of maternal obesity in pregnancy have large implications both for the mother and her offspring [2-10]. However, the underlying mechanisms are largely unknown.

Obesity is associated with a markedly elevated risk of type 2 diabetes (T2DM) [8-10]. Overweight of the mother also increases the offspring's predisposition to obesity and T2DM. Several mechanisms, not mutually exclusive, may explain the associations between exposure to obesity in utero and long-term metabolic disadvantages in the offspring, i.e., genetic and lifestyle factors as well as specific intrauterine effects. Epidemiological and clinical studies as well as experimental animal work have introduced the concept of Developmental Origins of Health and Disease. Prenatal environmental adversities may exert lifelong consequences by programming the offspring's cells, tissues, organs, their structure and function. The evidence for early programming is strongest for cardiovascular disease (CVD) and T2DM.

One developmental pathway to obesity is the foetal over-nutrition pathway [11], reflecting the effects of hyperinsulinaemia and other factors during foetal life. This creates conditions for later pathophysiological effects of an obesogenic environment. Alterations in maternal lipid metabolism may also contribute to the over-nutrition pathway [12]. Free fatty acids and triglycerides are elevated in mothers of obese neonates. Lipids play a key role in adipocyte differentiation; thus, increased transfer of free fatty acids might affect foetal adiposity by influencing the number, size or lipoprotein lipase activity of foetal fat cells. The adipoinsular axis is an endocrine feedback loop regulating hunger and fat storage through e.g., insulin and leptin. Hyperinsulinaemia (indicating a state of insulin resistance) and hyperleptinaemia are hallmarks of obesity. Cord blood leptin concentrations correlate positively with birth weight and adiposity. Excessive substrate exposure and insulin resistance (IR) may induce oxidative stress (OS) and damage to body organs.

Chronic stress and the hyperactivation of the hypothalamic-pituitary-adrenal (HPA) axis is another common feature in obesity, and cortisol is a potent hormone affecting early development.

Also, epigenetic mechanisms acquired in early life have been suggested to have phenotypic consequences later in development through their role in transcriptional regulation with relevance to the developmental origins of diseases including obesity $[13,14]$. Changes in epigenomic patterns and gene expression are believed to be a key underlying mechanism, resulting in phenotypic differences between individuals that persist across the lifespan. The epigenome is particularly susceptible to alterations during gestation, because the DNA synthesis rate is high and the DNA methylation patterning required for normal tissue development is established during this time. Epigenetic modifications in response to adversities may lead to metabolic imprinting of permanent alterations in genes involved in the regulation of energy homeostasis.

Despite the evidence that exposure to obesity in utero is associated with T2DM in the offspring, very little is known about how this exposure influences metabolic abnormalities. T2DM is associated with an increased risk for CVD and premature death. The influence of maternal overweight and obesity on ageing-related outcomes has not been studied previously. Even less is known on whether or not it would be possible to influence these metabolic outcomes by lifestyle modification in adulthood. 
Fig. 1. The hypothesis illustrated in this figure emphasizes the early mutual interaction between coexisting mechanisms that has to be tackled for a full understanding of the long-term consequences of maternal obesity. Specifically, IR, glucocorticoid overexposure, and OS may be involved in the modulation of TL, DNA methylation as well as DNA oxidative and mitochondrial damage as markers and mediators of the premature ageing caused by maternal obesity, leading to chronic disease and unhealthy ageing. This figure is public at www.dorian-fp7.eu (in the project flyer).

Iozzo et al.: Developmental ORIgins of Healthy and Unhealthy AgeiNg: The Role of Maternal Obesity - Introduction to DORIAN

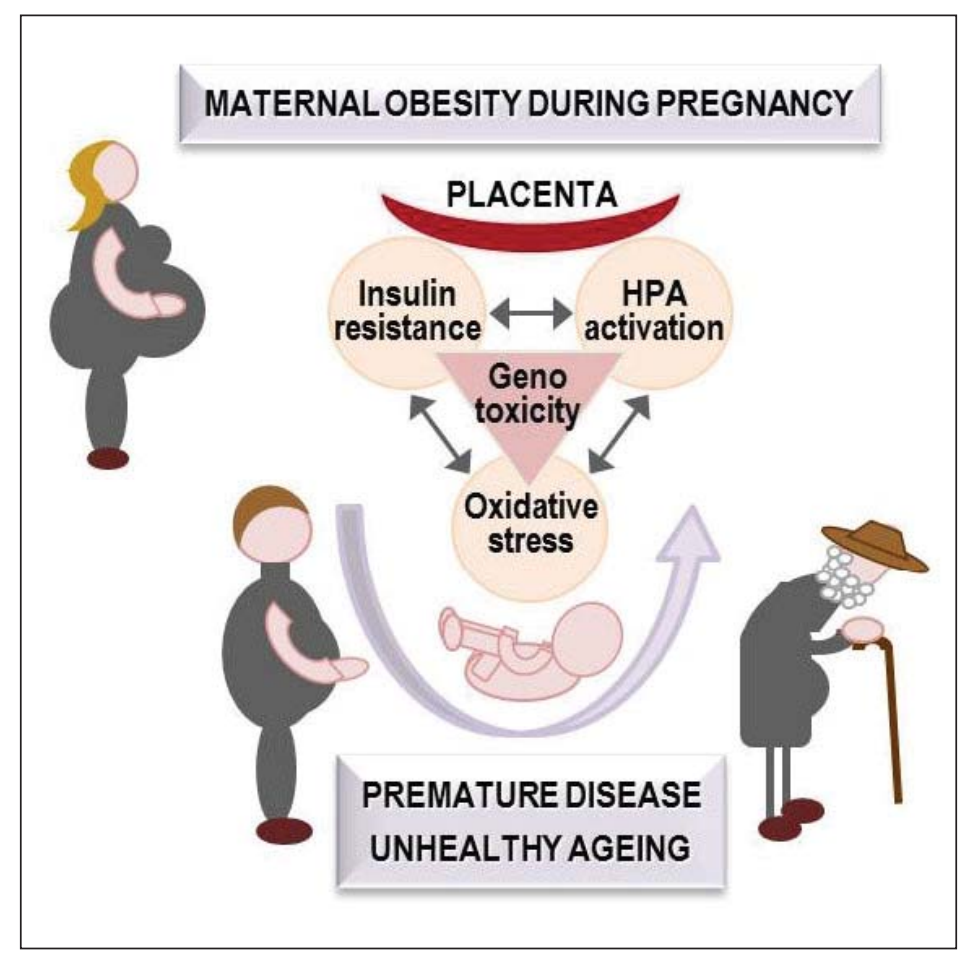

This review is focussed on the evidence implicating IR, chronic hormonal stress, OS and their consequences on premature DNA ageing in the pathogenesis of foetal programming of cardio-metabolic disorders in obese mothers' offspring (fig. 1).

\section{Insulin Resistance, Maternal Obesity, and Foetal Programming}

Obesity is typically associated with IR, leading to hyperinsulinaemia. In women, this trait seems to confer an increased risk for hypertension, central fat accumulation, inflammation and adverse pregnancy outcomes [15]. Maternal hyperinsulinaemia is associated with increased gestational weight gain and weight retention postpartum [16]. Human placental lactogen, which increases with advancing gestation, cytokines and elevated lipid concentrations have been correlated with the longitudinal changes in insulin sensitivity in pregnant women [17-19]. Visceral adiposity is commonly associated with the above health outcomes, and the mass of visceral fat increases during pregnancy in lean and to a greater extent in obese women.

Animal studies have shown that the offspring of female mice with diet-induced obesity develop IR, hypertension [20], adiposity and hyperphagia. They weigh more at birth because of increased fat at the expenses of lean mass [21], consistent with observations in piglets born to obese mothers, in which IR and greater body fat are accompanied by a depleted skeletal muscle mass (relative sarcopenia, i.e., an additional feature of unhealthy ageing), caused by a paucity of muscle cells [22]. In a rat study, Beck et al. [23] tried to mimic changes in food consumption patterns observed in pregnant women. The offspring of mothers, fed a highcarbohydrate diet, showed hyperglycaemia and hyperinsulinaemia during adulthood. Murabayashi et al. [24] demonstrated that maternal high-fat diet (mHFD) in mice causes 
Iozzo et al.: Developmental ORIgins of Healthy and Unhealthy AgeiNg: The Role of Maternal Obesity - Introduction to DORIAN

inflammatory changes in the adipose tissue of the offspring. In this study, foetal subcutaneous adipocytes of the offspring of high-fat-fed mice were significantly larger than those of control animals, and their subcutaneous adipose tissue showed macrophage infiltration in the stromal area as well as elevated expression of genes for chemokines mediating macrophage and monocyte chemotaxis and low levels of GLUT-4 mRNA. Studies in sheep, fed an obesogenic diet, documented tissue-specific defects in the insulin signalling cascade in the foetal myocardium and an impaired response to workload stress in the heart [25]. Furthermore, the hearts of offspring born to obese agouti mice dams showed an increased susceptibility to ischaemia-reperfusion injury [26]. In a sheep model, Yan et al. [27] evaluated the effects of maternal obesity on the skeletal muscle of the 22-month-old offspring. They observed a reduction in the phosphorylation of proteins involved in stimulating insulin signalling and an increase in the phosphorylation of proteins involved in attenuating insulin signalling in the offspring of mothers fed an obesogenic versus control diet. These findings were accompanied by higher intramuscular collagen and adipocyte infiltration as well as by an increase in fatty acid transporters. Signs of inflammation were also detected in the progeny of obese sheep compared to that of control sheep [28].

In humans, a greater flow of nutrients to the placenta and foetus in obese women promoted placental overgrowth, inflammation and increased foetal somatic growth [29]. IR in the mother predicted the size [30] and the degree of IR in the foetus [31]. The foetuses of obese mothers had a greater percentage of body fat and IR as well as higher cord leptin and interleukin-6 levels than foetuses of lean women. Moreover, strong positive correlations have been shown between foetal IR and maternal BMI, foetal adiposity or cord leptin. In obese women, maternal IR had the strongest correlation with neonatal adiposity which is also a risk factor for childhood obesity and longer-term metabolic dysfunction [2,32]. The maternal BMI before and during pregnancy as well as a high birth weight in the new-born were the strongest early predictors of adiposity in 2- to 4- and 9-year-old children and of the metabolic syndrome $(\mathrm{MeS})$ in 6- to 11-year-old children [3, 32, 33]. Maternal insulin sensitivity during pregnancy explained a considerable and additional proportion of the variance in birth weight and adiposity in the offspring [34].

Most animal and human studies so far focused on the effects of maternal obesity on early metabolic abnormalities in the offspring. In a small study on minipigs, we introduced the use of positron emission tomography as a way to measure (repeatedly over time) organ-specific insulin sensitivity. Our results showed that mother and offspring had very similar metabolic features at the time of birth and lactation, but strong factors, such as sex and growth (rate of weight change), may come into play after weaning [35].

\section{Chronic Stress, Obesity and Foetal Programming}

A large body of epidemiological evidence indicates a strong link between chronic stress, especially social stress, and metabolic disturbances [36]. The term stress is commonly defined as a state of threatened homeostasis [37]. A challenge by either intrinsic or extrinsic stressors to homeostasis induces specific response mechanisms, most prominently the sympathetic nervous system and the HPA axis, which result in a series of neural and endocrine adaptations known collectively as the stress response. While the adaptive response to acute stressors is advantageous for survival, periods of chronic stress or stressful life events may be maladaptive and have been associated with a variety of pathological conditions [3842]. Specifically, chronic stress represents a major risk factor for the development of abdominal obesity and the MeS, i.e., a cluster of metabolic factors that increase the risk to develop CVD and T2DM [42-44]. Animal models provide further evidence for an interaction 
Iozzo et al.: Developmental ORIgins of Healthy and Unhealthy AgeiNg: The Role of Maternal Obesity - Introduction to DORIAN

between the stress response and energy balance, such that exposure to stress mediates changes in feeding behaviour, caloric intake and body weight changes [36, 42-45]. Despite both strong epidemiological and animal model associations between chronic stress exposure and metabolic disturbances, the molecular basis underlying this relationship remains largely unknown.

Maternal obesity is an escalating health concern that increases the risk of complications during pregnancy and the risk of adverse foetal outcomes [46]. Through foetal programming, the adverse effects of maternal obesity may extend far beyond any acute consequence and may elevate the risk of various pathologies later in life [47]. In particular, evidence suggests that maternal obesity has a long-term impact on metabolism, including an increased risk of obesity and the MeS in adult offspring prenatally exposed to mHFD [48-51].

Beyond increased risk of metabolic disturbances, most notably IR, evidence shows adverse effects of mHFD on offspring's brain development, affective behaviour and cognition [52]. Specifically, animal studies have noted alterations in hippocampal and hypothalamic regions as well as in serotonergic, dopaminergic and opioid neurotransmitter systems, resulting in alterations of cognitive and affective behaviours in offspring born to obese mothers [53-60]. To date, relatively little research has focused on the long-term effects of mHFD on the offspring's stress response although the literature demonstrated common regulatory neural pathways between the stress response and metabolic homeostasis systems [61]. Nevertheless, nutritional status during gestation and lactation is recognized to have effects on the stress response. For example, a protein-restricted diet throughout gestation programs altered tissue-specific glucocorticoid action mediated by changes in expression profiles of glucocorticoid receptors (GR) and 11 $\beta$-hydroxysteroid dehydrogenase type 2 (11ß-HSD2) [62]. Furthermore, studies investigating prenatal stress, or glucocorticoid exposure, in rodents have revealed features associated with the MeS, namely hypertension and hyperglycaemia [63-66].

The limited number of studies that already have examined the effects of mHFD on the stress response, specifically the HPA axis function, demonstrated alterations in HPA axis responsiveness after an acute stressor in neonates and prepubertal rats exposed to mHFD [67]. Moreover, it has been shown that the neonatal HPA axis is sensitive to metabolic signals, including glucose and ghrelin [68], suggesting that changes in the level of metabolic signals that result from changes in maternal diet may influence the development of the neonate's HPA axis response. However, a comprehensive behavioural and endocrine characterization of the long-term impact of mHFD, combined with challenging conditions such as chronic stress, is still lacking. Accordingly, we propose to evaluate the long-term impact of mHFD and to study the interplay of metabolic disturbances and stress system dysfunction in the offspring under basal conditions as well as following adverse challenges.

Chronic stress is not only a risk factor for the development of metabolic disturbances but also for affective disorders. Dysregulation of the HPA axis as well as heightened stress reactivity are among the most consistent features in patients suffering from major depression (MD) [69-71]. Moreover, a comorbidity between MD and obesity exists, whereby depressed patients show higher rates of general obesity and related diseases; likewise, patients diagnosed as obese show increased rates of affective disorders [72-76]. Preliminary results indicate that antidepressants may not only be clinically effective in depression but may also have therapeutic effects in obesity-related disorders through changes in GR expression and subsequent restoration of the HPA axis activity [77-79]. These observations suggest that there is a common mechanistic link in the pathophysiologies of MD and obesity. However, to date it is unclear to which extent maternal obesity can modulate the risk for affective disorders and how antidepressant treatment will affect the emotional but also the metabolic phenotype in the offspring. 
Iozzo et al.: Developmental ORIgins of Healthy and Unhealthy AgeiNg: The Role of Maternal Obesity - Introduction to DORIAN

\section{Role of 11ß-Hydroxysteroid Dehydrogenase Type 2 in Developmental Programming}

The developing foetus is maintained in a low glucocorticoid environment, to protect against the potent effect of glucocorticoids that accelerate foetal organ maturation in a trade-off against overall growth. To maintain the glucocorticoid gradient between mother and foetus, physiological glucocorticoids are catabolized by foetal and placental 11 $\beta$-HSD2, converting active glucocorticoids to the inactive 11-keto derivative. The hypothesis then developed that variations in foeto-placental $11 \beta$-HSD2 may underlie prenatal glucocorticoid programming [80]. The observation that placental 11 $\beta$-HSD2 activity correlated directly with birth weight in rodent [81] and in most human studies [82-85], suggests that normal variation in foetal exposure to maternal glucocorticoids has an impact on foetal growth.

Furthermore, inhibition, genetic deficiency or by-pass (using poor-substrate steroids such as dexamethasone or betamethasone) of placental 11 $\beta$-HSD2 in model species and humans was associated with reduced pregnancy duration, lower birth weight and programmed outcomes, cardio-metabolic as well as psychiatric, in the offspring [81, 86-99]. Humans who were homozygous / compound heterozygous for deleterious mutations in HSD11B2 had low birth weight compared with their largely heterozygous siblings [86, 88, 100]. Similarly, Hsd11b2-/- mice had lower full-term weight [92].

Furthermore, Finnish women who voluntarily ate larger amounts of liquorice-containing foodstuffs (liquorice contains an inhibitor of 11ß-HSD) in pregnancy had shorter gestations, and their children showed poorer cognitive function and affective disturbances (notably markedly increased rates of attention deficit hyperactivity disorder) coupled with modest HPA axis hyperactivity $[101,102]$. The central programming of the brain and behaviour by glucocorticoids was replicated in animal models. Hence, maternal administration of dexamethasone or prenatal stress produced offspring that appeared to be more anxious as adults. Thus, late gestational dexamethasone exposure in rats impaired the offspring's 'coping' behaviours in aversive situations later in life as exemplified by reduced exploration in the open field test and the elevated plus maze [103]. Such an increase in anxiety-like behaviour was evident as early as in postnatal week 10 in rats prenatally exposed to dexamethasone [104]. Moreover, 11 $\beta$-HSD2 appears important in these events since treatment of pregnant rats with an 11 $\beta$-HSD inhibitor just as gene deletion in mice produced offspring with enhanced anxiety-related behaviours [90, 92].

The mechanisms of these programmed effects are tissue-specific and involve glucocorticoid-driven changes in target organ structure, gene expression and gene function. Epigenetic processes maintaining such effects have been advocated [64, 90, 93, 95, 103, 105-110]. Indeed, the key genes involved in HPA axis activity, i.e., those coding for corticotropinreleasing hormone and arginine vasopressin, GR and 11ß-HSD2 itself, showed altered expression in models of programming, and the promoters of all three encoding genes showed persisting changes in methylation in response to early-life environmental challenges [111114]. Methylation of DNA during gestation is in part determined by the availability of methyl donors [115], and placental 11ß-HSD2 impacts on placental transport of key methyl donors [116], implying a possible additional role in determining foetal epigenetic status.

A core issue in foetal programming is to determine the locus of action of environmental challenges, specifically distinguishing indirect effects upon the mother from more direct impacts upon the placenta and/or the foetus. This has been achieved by crossing male and female mice heterozygous for a null allele of $H s d 11 b 2$. This results in wild-type, heterozygous and homozygous null Hsd11b2 offspring in the same dam. Since placental 11ß-HSD2 in the labyrinth zone is derived from the foetal genotype, this design afforded a clear differentiation of foeto-placental from maternal effects. In this model, birth weight and offspring affective behaviour followed the foeto-placental genotype [92], excluding maternal effects from this 
Iozzo et al.: Developmental ORIgins of Healthy and Unhealthy AgeiNg: The Role of Maternal Obesity - Introduction to DORIAN

manipulation of $11 \beta$-HSD2. Of course, the Hsd11b2-/- offspring also lacked the enzyme in kidney and were thus hypertensive and hypokalaemic [117], which complicated the assessment of cardio-metabolic programming. Studies of tissue-specific knockout of $11 \beta$-HSD2 in foetal organs will allow distinction of the relative importance of the placental and individual foetal tissue 'barriers' to glucocorticoids.

An additional and important level of impact of $11 \beta$-HSD2 is on placental function per se. In the heterozygous cross model, placentas completely lacking 11 $\beta$-HSD2 showed restricted growth in late gestation, even before foetal growth was retarded [98]. In late mid-gestation, placental amino acid transport to Hsd11b2-/- offspring was increased, suggesting compensation for placental dysfunction. However, in the near term, the Hsd11b2-/- placenta was failing with markedly reduced placental glucose transport and decreased glucose transporter 3 expression. The late-gestation $\mathrm{Hsd} 11 \mathrm{b2}-/-$ placenta lacked the normal increase in density of foetally derived blood vessels and showed reduced expression of the key angiogenic factor vascular endothelial growth factor (normally down-regulated by glucocorticoids [118]) and a key angiogenic transcription factor, i.e., peroxisomal proliferator-activated receptor gamma. Glucocorticoids and 11 $\beta$-HSD inhibitors advanced apoptosis in the term placenta [119]. Such underweight, under-vascularized, and under-functioning placentas are poorly equipped to supply the rapidly growing and maturing near-term foetus.

\section{Relationship between Glucocorticoid and Nutritional Programming}

Intriguingly, 11 $\beta$-HSD2 itself appeared to be a target for foetal programming, with persisting reductions in renal 11 $\beta$-HSD2 mRNA levels and increased mineralocorticoid activity of glucocorticoids in sheep exposed to under-nutrition [120]. In humans, children exposed to the horrors of the Nazi Holocaust showed reduced renal 11 $\beta$-HSD2 activity in old age, with the greatest effect seen in those youngest at traumatization [121]. These data suggest that $11 \beta$-HSD2 is a programming target in humans, possibly to maximize renal sodium retention in what may be anticipated to be a starvation-associated sodium-poor environment.

Low protein diet in pregnancy caused an increase in maternal and foetal glucocorticoid levels [122-123], together with a decrease in placental 11ß-HSD2 activity [62, 124, 125]. Conversely, exposure to dexamethasone during pregnancy decreased maternal food intake [126] and reduced maternal weight gain [91]. These results suggest that there are common mechanisms underpinning both nutritional and glucocorticoid developmental programming. Feeding low-protein diet to the pregnant dams of heterozygous $H s d 11 \mathrm{~b} 2$ crosses showed that, although both maternal undernutrition and 11ß-HSD2 deficiency reduced foetal growth and both involved foeto-placental overexposure to glucocorticoids, the mechanisms were distinct. Thus, 11 $\beta$-HSD2 insufficiency increased foeto-placental exposure to maternal glucocorticoids, whereas low-protein diet activated the foetal HPA axis to produce increased foetal glucocorticoid levels [127]. Consistent with this, prenatal under-nutrition increased levels of adrenal steroidogenic enzymes at birth [128].

Studying a unique human population in Motherwell, Scotland, who were advised by their obstetrician to eat $0.45 \mathrm{~kg}$ of red meat a day and to avoid carbohydrate-rich food during pregnancy, revealed that this abnormal diet programmed high blood pressure [129], high cortisol levels [130], and heightened HPA axis responses to stress [131]. These programmed phenotypes may be underpinned by the associated change in methylation patterns of $11 \beta$-HSD2-, GR-, and insulin-like growth factor 2-encoding genes [132].

With the obesity epidemic producing more babies born to obese mothers, it is of concern that there is also adverse programming of cardio-metabolic outcomes in these offspring [133, $134]$, and it now becomes crucial to determine if $11 \beta$-HSD2 plays a role in mediating these effects. 
Iozzo et al:: Developmental ORIgins of Healthy and Unhealthy AgeiNg: The Role of Maternal Obesity - Introduction to DORIAN

\section{Oxidative Stress}

Life expectancy has greatly increased in the last century although, in most industrialized countries, this has been paralleled by an increased incidence of neurodegenerative disorders in addition to cardiovascular and metabolic pathologies. The $p 665 h c$ gene has emerged as a novel gerontogene affecting health throughout life and during ageing. In the last decade, studies on p66Shc knock-out mice have indicated that this gene is a crucial regulator of reactive oxygen species levels and is involved in age-related dysfunctions. p66Shc-/- mice indeed showed a healthy phenotype characterized by greater brain and behavioural plasticity in addition to reduced OS, fat accumulation and incidence of metabolic- as well as cardiovascular pathologies [135-141]. Studies performed in a semi-naturalistic setting, involving exposure to low temperatures and food shortage, indicated that $p 66 \mathrm{Sh} c$ has been conserved through evolution because of its role as 'thrifty gene' in energy metabolism. This feature, which increases the probability for survival in harsh natural conditions, can be deleterious when food is constantly available, as in westernized lifestyles, leading to fat accumulation and thus predisposing to metabolic, CVD and accelerating brain ageing.

The $p 66 S h c$ gene appears to be one of the converging points linking OS, metabolism, and the genetics of ageing. So far, a number of animal models, developed to study the ageing process, suggested a relationship between changes in general metabolism or in the cellular redox milieu and longevity [142-148]. P66Shc-/- mice are characterized by reduced OS, elevated resistance to high-fat-induced obesity, and, more importantly, are long-lived, representing a unique opportunity to study the ageing process in vivo, and thus the relationship between longevity and health [135-141]. Being at the crossroad of signalling pathways involved in both central and peripheral stress responses and in the regulation of energy homeostasis, p66Shc is a good candidate molecule to address the mechanisms underlying healthy ageing and to be targeted for the development of novel pharmacological tools for the prevention or cure of age-related pathologies. In humans, ageing largely contributes to metabolic decline and to the aetiology of related pathological conditions such as T2DM, CVD and stroke [149]. IR and abdominal obesity, often observed in older adults, are main components of the MeS, a pathological condition characterized by multi-organ morbidity [150,151]. The increased secretion of pro-inflammatory cytokines often observed during ageing interferes with insulin action, and these cytokines derive from both the age-associated accrual of visceral fat and increasing numbers of senescent cells [152]. However, a growing body of evidence shows that the incidence of obesity, and the often associated MeS, is increasing in the young population, especially in western countries [153]. These morbid conditions are accompanied by a whole metabolic unbalance with high levels of OS and inflammation in addition to shorter telomeres (that correlate with increasing BMI), overall resembling a form of precocious ageing [154]. Furthermore, patients with $\mathrm{MeS}$ are often characterized by a higher incidence of mood and cognitive dysfunctions than the general age-matched population that, in turn, emerge as significant risk factors for aggravation of MeS and the related health outcomes, particularly CVD and type T2DM [155-160]. Thus, overall, alterations in metabolism and body fat distribution certainly play a role in a vicious cycle that can precipitate the ageing process and the onset of diseases [149]. The mechanisms that account for these phenomena are incompletely understood; however, longevity genes might be involved. Very recently, Fadini et al. [154] proposed SIRT1, p66Shc and the mammalian TOR (mTOR) / RSK / AMPK pathways to play a role in this clinical context because they integrate nutrient bioavailability, OS as well as metabolism and because biological plausibility supports their reciprocal interconnections.

Given the obesity epidemic in western countries, a main research question is the role of maternal obesity in setting up a state of individual susceptibility to metabolic and neurode- 
Iozzo et al.: Developmental ORIgins of Healthy and Unhealthy AgeiNg: The Role of Maternal Obesity - Introduction to DORIAN

generative disorders at adulthood. The data available for humans indicate that the foeti of obese mothers are exposed to higher levels of insulin. Overall, gestational IR and obesity favour hyperglycaemia, relative fat excess and sarcopenia as well as greater birth weight and higher blood pressure in the offspring which are recognized risk factors for CVD, T2DM and cognitive impairment. It is possible to hypothesize that reduced exposure to OS from early development throughout life might protect the $p 66 S h c_{-} /-$mutants from the negative effects of free radicals, resulting in a more efficient homeostatic control and better abilities to cope with changes in the internal milieu, attenuating the effects of ageing on the nervous system and causing an improved overall health status. Those mice which showed reduced OS, were lean and resistant to obesity, atherosclerosis, ischaemic injury, diabetes, neurodegeneration as well as cancer, and showed increased longevity, were an ideal model to study the mechanistic hypothesis underlying the relationship between maternal obesity, offspring metabolism, OS and longevity.

\section{DNA Expression and Structure and Its Alterations}

\section{Epigenetic Regulation (Influences)}

In the last decade, epigenetic changes in the human genome have been recognized as a very important determinant of cellular senescence and age-related diseases [161, 162]. Epigenetics refers to modifications of the genome without change in the primary DNA sequence that can be inherited both mitotically and meiotically.

The most widely studied and best characterized epigenetic mark is DNA methylation: it consists of a catalytic addition to the fifth carbon position of cytosine nucleotides of a methyl group throughout the genome within $\mathrm{CpG}$ dinucleotides, the so-called CpG islands. DNA methyltransferases (DNMTs) enzymes (DNMT1, DNMT3A and DNMT3B) are responsible for methylation pattern acquisition during gametogenesis, embryogenesis and somatic tissue development.

Most of the CpG islands are located in the promoter region and the first exon of approximately half of all human protein-coding genes, and remain free of methylation. In the normal cell, only imprinted genes, genes whose expression is restricted to male or female germ line and tissue-specific genes are silenced by methylation mechanisms.

Promoter hypermethylation generally results in a decreased gene transcription or abolishes gene expression. Changes in methylation of $\mathrm{CpG}$ islands correlate with altered gene expression and can contribute to a disease phenotype.

Ageing and age-related diseases are generally characterized by genome-wide hypomethylation and promoter-specific hypermethylation [161,162].

Notably, modifications are reversible and are, therefore, a potential target for therapeutic intervention. In fact, numerous drugs that specifically target DNMTs are currently tested in ongoing phase II-III clinical trials for cancer therapy [163].

Because DNA methylation patterns are largely established in utero, nutritional insult during a critical period of gestation may alter the epigenetic state of the foetal genome, inducing stable changes in gene expression that may be sustained throughout the lifespan of an individual [164].

Indeed, data from animal models suggest that maternal nutrition status can influence metabolic phenotypes through epigenetic changes [165-167]. Accordingly, a recent study showed that methylation status of CpGs in the promoters of candidate genes in DNA extracted from umbilical cord tissue obtained at birth were related to adiposity in later childhood and to information on the mother's diet during pregnancy [168]. These data strongly support that epigenetic changes occurring during gestation, as mediated by the maternal diet, have a 
Iozzo et al.: Developmental ORIgins of Healthy and Unhealthy AgeiNg: The Role of Maternal Obesity - Introduction to DORIAN

prolonged impact on adiposity and related metabolic phenotypes which in turn would be expected to influence the risk for diabetes and its complications.

However, the understanding of the mechanism by which maternal nutrition can modify the epigenome requires further research. Specifically, we hypothesize that other combinations of gene promoters may have a central position in epigenetic control of maternal obesity and age-dependent methylation. Promoter-specific DNA methylation in selected candidate genes (e.g., cell cycle regulation genes) can provide evidence for the influence of maternal diet during gestation on foetal gene expression as well as their roles in the regulation of cellular senescence and premature ageing. In addition, as outlined above, placental $11 \beta$-HSD2 impacts on placental transport of key methyl donors, and the key genes as well as gene promoters involved in HPA axis activity altered expression in models of programming. Therefore, we propose to examine the synergy between over-nutrition and HPA axis dysregulation in establishing epigenetic changes during foetal programming in offspring of obese mothers. Furthermore, it will be of great interest to analyze whether lifestyle changes might reverse promoter methylation levels.

The use of now available next-generation sequencing platforms can also help to identify genes susceptible to epigenetic modifications in response to nutritional exposure in utero.

\section{Methods to Study the Epigenome}

An increasing number of human diseases has be shown to be associated with epigenetic alterations [169]. Therefore, computational epigenetics has become an important branch of computational biology. Computational epigenetics is concerned with the development of bioinformatics methods to complement experimental epigenetics research, and, as such, has developed a range of bioinformatics methods for the analysis of second-generation sequencing data from epigenetic studies [170].

Epigenetic alterations that are being studied include cytosine methylation and chromatin modifications. Chromatin modifications are usually examined using techniques such as immunoprecipitation of chromatin followed by sequencing of the corresponding DNA fragments. DNA methylation can be studied using bisulphite sequencing of specific regions or, indeed, of the whole human genome [171]. While whole-genome bisulphite DNA sequencing offers single-nucleotide resolution of DNA methylation, it is currently prohibitively expensive for use on a large scale. A solution for this is the affinity-based enrichment of methylated DNA, using methyl-CpG-binding domain (MBD) proteins followed by next-generation sequencing (MBD-seq) [172]. The advantage of the selective enrichment of methylated DNA is that it allows the routine analysis of the methylation states of large genomes, such as those of human and mouse. We propose to enrich the methylated fraction of the genomic DNA of the respective human and mouse sample by affinity-based enrichment using MBD-seq by the Illumina Genome Analyzer platform in order to study the differential methylation in target study models. A pipeline will be developed for aligning sequence reads to the reference genome, using existing next-generation sequencing analysis tools such as Novoalign (www.novocraft.com) or bwa [173] for the Illumina platform. Subsequently, the data will be analyzed using specific tools for the analysis of methylated DNA sequencing data, such as MeQA [174]. Loci exhibiting differential methylation patterns will be compared to their syntenic regions in human and analyzed with motif-finding software, such as Meme [175], in order to search for conserved patterns in these loci. Since alternative splicing has been linked to predisposition to obesity [176], alternative transcripts of genes associated with differentially methylated loci will be studied, and their conservation will be explored in the human genome. By selecting specific biomarkers, we will develop an automated sequence-based method for the early diagnosis of disease susceptibility. 
Iozzo et al.: Developmental ORIgins of Healthy and Unhealthy AgeiNg: The Role of Maternal Obesity - Introduction to DORIAN

\section{Oxidative DNA Damage to Telomeres and Chromosomes}

Telomeres are DNA-protein complexes at the ends of chromosomes, composed of tandem $\left(5^{\prime}\right.$-(TTAGGG)n- $\left.3^{\prime}\right)$ repeats, and ranging between a few and $15 \mathrm{~kb}$ in length. Their main function is to protect chromosome integrity and stability from nucleolytic degradation, unnecessary recombination and interchromosomal fusion. It is now well established that telomeres shorten with every cell cycle because DNA polymerase is unable to fully replicate the 3 '-end of the DNA strand. Thus, telomere shortening, ranging between 30 and 150 base pairs with each cell division, is physiologically associated with ageing. Telomerase is a ribonucleoprotein reverse transcriptase that maintains telomere length (TL) by adding telomeric DNA to existing telomeres. While it is well expressed and active in germ cells, telomerase abundance decreases with gestational age and differentiation progress; eventually its expression becomes poor in somatic cells of children and adults.

When TL reaches a critical limit, the cell undergoes senescence or apoptosis, or oncogenic transformation. In addition to its natural and age-related rate, telomere shortening may be accelerated by additional factors such as epigenetic regulation, OS and many others which are currently under investigation.

Excessive or accelerated telomere shortening affects health and lifespan at multiple levels. In adults, TL inversely correlated with age, hypertension, coronary heart disease, T2DM, IR, cancer and mortality rate. Moreover, neurologic/psychiatric conditions such as MD, schizophrenia, migraine, mild cognitive impairment and Alzheimer disease are also associated with shorter telomeres [177].

A growing body of evidence shows that telomere shortening rate can be increased by several lifestyle factors, including obesity, diet composition and psychosocial stress among the prominent ones.

BMI has been shown to correlate with biomarkers of DNA damage independently of age [178], and shorter leucocyte telomeres have been found in obese women compared to a control group [179]. Deregulation of adipokines, local and systemic OS, increased circulating oxidizing agents and lower levels of antioxidant enzymes, such as catalase and dismutase [180], are likely to represent the main mechanisms underlying accelerated telomere shortening and cell senescence in obese subjects. Shorter telomeres were found in hypertrophic adipocytes of both visceral and subcutaneous fat from obese and T2DM patients when compared to control subjects and were shown to be directly associated with cell size and lipid peroxidation and inversely related with adiponectin levels [181]. Although the association between obesity and accelerated telomere shortening is well accepted, the direction of the relationship is still controversial. A longitudinal study in a cohort of 2,721 elderly subjects found that shortening of TL was associated with adiposity. However, the correlation was significant with some obesity-related parameters (i.e., \% body fat, subcutaneous fat and leptin) but not with others (i.e., BMI and visceral fat), which leaves the mutual interplay between obesity and TL still uncertain [182].

Some authors showed that in addition to excessive food intake and overweight/obesity, dietary composition affects the rate of telomere shortening. In particular, TL was positively associated with the intake of fibre and antioxidants, and negatively associated with polyunsaturated fatty acids as well as protein [183]. In rat models, diet restriction and protein restriction led to reduced growth rate, reduced DNA damage, reduced telomere shortening and increased lifespan [184].

Psychosocial stress was associated with increased release of glucocorticoid hormones, which have been shown to increase reactive oxygen species by reducing antioxidant protein levels, thus further enhancing OS-dependent telomere shortening. Shorter telomeres and reduced telomerase activity have been found in women experiencing stress in their daily life compared to controls [185]. 
Iozzo et al.: Developmental ORIgins of Healthy and Unhealthy AgeiNg: The Role of Maternal Obesity - Introduction to DORIAN

Although only few longitudinal studies investigating the association between TL and obesity exist, it seems that weight gain, rather than the obese status per se, is a more important factor affecting telomere shortening rates [186]. This observation, together with the epidemic of overweight and obesity in children, urges the need to understand if early development may be affected by premature ageing due to nutritional and inflammatory features during childhood, including the pre/post-natal periods. In a case control study on 793 children aged 2-17 years, leucocyte telomeres were $~ 24 \%$ shorter in obese than in non-obese children [186], with no difference between males and females. Other authors did not find any [187] or only found sex-related differences [188] between obese and lean subjects.

Growing evidence from epidemiological, clinical and molecular studies suggests that intrauterine life is critical in the developmental programming of health in adult life, especially with regard to chronic conditions that are associated with systemic inflammation and OS. However, the mechanisms and pathways accounting for prenatal-dependent postnatal susceptibility to diseases are still unrevealed. Telomere shortening / deficient repair capacity may be sensitive to nutritional, hormonal or psychological stresses during the intrauterine period.

Only few and recent papers have addressed TL in the foeto-placenta unit and cord blood to provide evidence of intrauterine programming towards a premature senescent phenotype in the infant [189]. Inter-individual variation in the initial length of telomeres was remarkable, in spite of its high heritability. Studies in animal models [184, 190-192] have shown that adverse conditions during intrauterine life, as well as prenatal cortisol administration in chickens [192], were associated with increased telomere shortening and decreased telomerase activity. Other studies in humans found that adverse conditions during pregnancy, such as foetal growth restriction, diabetes, preeclampsia and exposure to psychosocial stress, were associated with accelerated telomere shortening in the offspring [193-197]. Increased telomerase activity was found in the cord blood obtained from type 1 diabetic women, but not in the cord blood of women with T2DM or gestational diabetes; however, the groups did not differ with regard to TL. Telomerase activity in the foeto-placenta unit might have been enhanced to counterbalance the pro-inflammatory and pro-oxidant environment that characterizes diabetes and might indicate a potentially dangerous intrauterine environment [192, 197].

Beside telomere shortening, mutations and aberrations of mitochondrial DNA (mtDNA) are ageing-related hallmarks. Shorter telomeres, decreased mtDNA content, increased OS and hypoadiponectinaemia were found in T2DM patients [181]. A model integrating telomere biology and mitochondrial function has been suggested by several studies. In fact, a telomerep53-mitochondrion axis may account for many processes shown to be important in pathophysiological ageing [198]. According to this model, telomere shortening is the driving force that generates mitochondrial dysfunction via activation of the transcription factor $\mathrm{p} 53$. Then, mitochondrial dysfunction leads to impaired metabolic- as well as energetic homeostasis and increased OS which sustain a feed-forward cycle of further DNA damage and mitochondrial dysfunction.

Due to its proximity to the site of generation of reactive oxygen species and free radicals, mtDNA is highly susceptible to mutations. In tissues with a high metabolic rate and low proliferative index (e.g., brain and heart), mutations accumulate faster than in other tissues due to a greater potential exposure to OS. A specific deletion of 4,977 base pairs, called the 'common deletion', has been detected with high frequency in tissues of adult subjects, but not in foetal and young tissues. Mitochondrial DNA 4977 bp deletion (mtDNA ${ }^{4977}$ ) accumulated with age in clinically normal hearts as a consequence of the high metabolic rate of cardiomyocytes. Higher levels of mtDNA ${ }^{4977}$ were found in cardiac-muscle specimens of patients with atrial fibrillation [199] or suffering from coronary atherosclerotic heart disease [200]. Higher 
Iozzo et al.: Developmental ORIgins of Healthy and Unhealthy AgeiNg: The Role of Maternal Obesity - Introduction to DORIAN

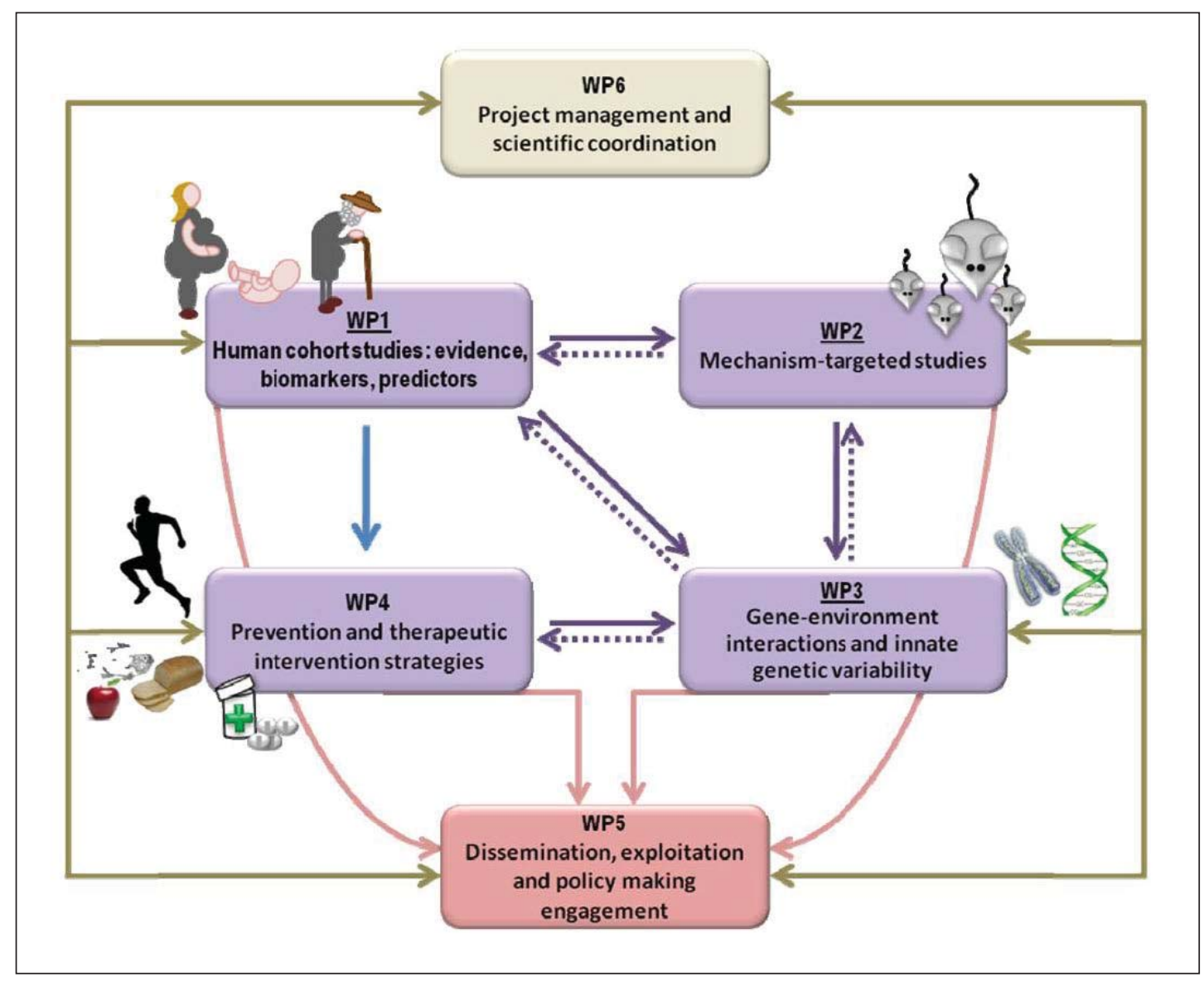

Fig. 2. DORIAN integrates human clinical projects with research focussing upon basic mechanisms. It comprises four research work packages (WPs). There are two additional WPs: WP5 is dedicated to dissemination and WP6 to management. This figure is public at www.dorian-fp7.eu.

mtDNA ${ }^{4977}$ levels were also detected in blood cells of coronary artery disease patients, independently of age and sex. However, the amount of $\mathrm{mtDNA}^{4977}$ neither correlated with atherosclerotic risk factors nor clinical parameters [201]. Heritability of specific mitochondrial deletions and the effect of maternal mtDNA alterations on the foeto-placenta unit have not been investigated yet. Nevertheless, the study of frequency of mtDNA 'common deletion' in conditions potentially characterized by variable levels of systemic inflammation and OS along with altered metabolic homeostasis (i.e., obesity, IR, diabetes and the resulting intrauterine environments) may be crucial to tackle in the developmental phase of life.

\section{Operationalization of Work in DORIAN}

Figure 2 is the pert diagram of DORIAN, illustrating the interconnection between six work packages.

Work package 1 (WP1) will address the long-, medium- and short-term effects of maternal obesity. The former will be studied in the Helsinki Birth Cohort Studies (HBCS) and the Arvo Ylppö Longitudinal Study (AYLS). HBCS-I and HBCS-II include individuals born 1924-1944, allowing to examine the effects of maternal obesity on ageing and the occurrence of chronic 
Iozzo et al.: Developmental ORIgins of Healthy and Unhealthy AgeiNg: The Role of Maternal Obesity - Introduction to DORIAN

non-communicable diseases through the lifespan in humans. AYLS includes young adults, followed up from birth, in whom the effects of maternal obesity on early risk determinants will be sought. Finally, WP1 includes investigations in pregnant mothers and their offspring at birth, enabling to dissect direct effects of the uterine environment from post-natal modulators.

Work package 2 (WP2) will explore the effects of maternal obesity in rodents which are suited to examine specific mechanisms and outcomes over the entire lifespan. In particular, the consequences of maternal IR will be explored in models that are prone to develop obesity and IR upon high-fat feeding. The consequences of hormonal stress will be examined in animals that are knocked-out for the placental degrading enzyme 11ß-HSD2. The modulating actions of OS will be investigated in the p66 knock-out mouse model. Then, the findings of WP2 will be intertwined with those of WP1, in which biomarkers reflective of these pathways are measured in neonates, young adult, and elderly humans born to obese and lean mothers.

Work package 3 (WP3) will receive biological samples from WP1 and WP2 to investigate genotoxicity, focusing on the shortening of telomeres that are reflective of DNA ageing and oxidative damage, and on epigenetic changes at birth by using a genome-wide approach (as described above) or a targeted (candidate gene) approach, looking at specific genes that are known to be associated with CVD or metabolic diseases.

Work package 4 (WP4) will address prevention and reversibility of the effects of maternal obesity by using animal or human models as appropriate, and tools like PET and MR imaging to detect longitudinal changes in vivo at the specific tissue level (skeletal muscle, liver, heart, adipose tissue and brain) and in target molecular pathways (glucose and lipid metabolism, IR). Interventions will primarily be concerned with lifestyle changes, but drugs with known and selective effects on the processes of interest may also be used in rodents.

Work package 5 (WP5) will be concerned with dissemination which is an important objective of the project, addressing the scientific community, primarily via publications and congresses and the stakeholders via dedicated workshops with the industry and policy makers. Means to transfer the information to the public, especially to reach mothers and families, have been carefully considered in the selection of DORIAN partners and in the design of the communication strategy. Importantly, we believe that dissemination is a two-way process in which we will use tools and create occasions to listen and learn from citizens and patients, providing their insight on what hold them from succeeding in good nutritional and lifestyle choices. We will learn from the experience of those who have participated in more successful campaigns against unhealthy habits, for example cigarette smoking.

Work package 6 (WP6) will provide solid tools and qualified partners to monitor the progress of the project and of its dissemination in order to ensure a continuous exchange between partners and the timely delivery of reports and outcomes.

\section{Acknowledgements}

Funding for the project is provided by EU (FP7) Project 'Developmental Origin of Healthy and Unhealthy Ageing: the Role of Maternal Obesity' (DORIAN) (grant n. 278603). Additional support was received by the Italian Ministry of Health (Italia-Usa Project), Fasc.11US/14/1 (to FC), and the European Foundation for the Study of Diabetes (EFSD/Roche educational grant 2009, to PI).

\section{Disclosure Statement}

The authors have nothing to disclose in relation to this work. 
Iozzo et al.: Developmental ORIgins of Healthy and Unhealthy AgeiNg: The Role of Maternal Obesity - Introduction to DORIAN

\section{References}

1 Kim SY, Dietz PM, England L, Morrow B, Callaghan WM: Trends in pre-pregnancy obesity in nine states, 19932003. Obesity (Silver Spring) 2007;15:986-993.

-2 Catalano PM, Ehrenberg HM: The short- and long-term implications of maternal obesity on the mother and her offspring. BJOG 2006;113:1126-1133.

3 Boney CM, Verma A, Tucker R, Vohr BR: Metabolic syndrome in childhood: association with birth weight, maternal obesity, and gestational diabetes mellitus. Pediatrics 2005;115:e290-296.

4 Catalano PM, McIntyre HD, Cruickshank JK, McCance DR, Dyer AR, Metzger BE, Lowe LP, Trimble ER, Coustan DR, Hadden DR, Persson B, Hod M, Oats JJ, for the HAPO Study Cooperative Research Group: The Hyperglycemia and Adverse Pregnancy Outcome Study: associations of GDM and obesity with pregnancy outcomes. Diabetes Care 2012;35:780-786.

5 Dabelea D, Crume T: Maternal environment and the transgenerational cycle of obesity and diabetes. Diabetes 2011;60:1849-1855.

6 Martorell R, Stein AD, Schroeder DG: Early nutrition and later adiposity. J Nutr 2001;131:874S-880S.

7 Owans LA, O'Sullivan EP, Kirwan B, Avalos G, Gaffney G, Dunne F; ATLANTIC DIP Collaborators: ATLANTIC DIP: the impact of obesity on pregnancy outcome in glucose-tolerant women. Diabetes Care 2010;33:577-579.

8 Pettitt DJ, Knowler WC: Diabetes and obesity in the Pima Indians: a cross-generational vicious cycle. J Obesity Weight Regul 1988; 7:61-65.

\9 Pirkola J, Pouta A, Bloigu A, Miettola S, Hartikainen AL, Järvelin MR, Vääräsmäki M: Prepregnancy overweight and gestational diabetes as determinants of subsequent diabetes and hypertension after 20-year follow-up. J Clin Endocrinol Metab 2010;95:772-778.

10 Pirkola J, Pouta A, Bloigu A, Hartikainen AL, Laitinen J, Järvelin MR; Vääräsmäki M: Risks of overweight and abdominal obesity at age 16 years associated with prenatal exposures to maternal prepregnancy overweight and gestational diabetes mellitus. Diabetes Care 2010;33:1115-1121.

-11 Yajnik CS. Nutrient-mediated teratogenesis and fuel-mediated teratogenesis: two pathways of intrauterine programming of diabetes. Int J Gynaecol Obstet 2009;104(suppl 1):S27-S31.

-12 Schaefer-Graf UM, Graf K, Kulbacka I, Kjos SL, Dudenhausen J, Vetter K, Herrera E: Maternal lipids as strong determinants of fetal environment and growth in pregnancies with gestational diabetes mellitus. Diabetes Care 2008;31:1858-1863.

13 Gluckman PD, Hanson MA: Developmental and epigenetic pathways to obesity: an evolutionary-developmental perspective. Int J Obes (Lond) 2008;32(suppl 7):S62-S71.

14 Relton CL, Groom A, St Pourcain B, Sayers AE, Swan DC, Embleton ND, Pearce MS, Ring SM, Northstone K, Tobias JH, Trakalo J, Ness AR, Shaheen SO, Davey Smith G: DNA methylation patterns in cord blood DNA and body size in childhood. PLoS One 2012;7:e31821.

15 Catalano PM. Obesity, insulin resistance, and pregnancy outcome. Reproduction 2010;140:365-371.

16 Scholl T0, Chen X: Insulin and the 'thrifty' woman: the influence of insulin during pregnancy on gestational weight gain and postpartum weight retention. Matern Child Health J 2002;6:255-261.

17 Ryan EA, Enns L: Role of gestational hormones in the induction of insulin resistance. J Clin Endocrinol Metab 1988;67:341-347.

18 Hotamisligil GS, Murray DL, Choy LN, Spiegelman BM. Tumor necrosis factor alpha inhibits signaling from the insulin receptor. Proc Natl Acad Sci U S A 1994;91:4854-4858.

19 Kirwan JP, Hauguel-De Mouzon S, Lepercq J, Challier JC, Huston-Presley L, Friedman JE, Kalhan SC, Catalano PM: TNF-alpha is a predictor of insulin resistance in human pregnancy. Diabetes 2002;51:2207-2213.

-20 Samuelsson AM, Matthews PA, Argenton M, Christie MR, McConnell JM, Jansen EH, Piersma AH, Ozanne SE, Twinn DF, Remacle C, Rowlerson A, Poston L, Taylor PD: Diet-induced obesity in female mice leads to offspring hyperphagia, adiposity, hypertension, and insulin resistance: a novel murine model of developmental programming. Hypertension 2008;51:383-392.

21 Sewell MF, Huston-Presley L, Super DM, Catalano P: Increased neonatal fat mass, not lean body mass, is associated with maternal obesity. Am J Obstet Gynecol 2006;195:1100-1103.

22 Hoffman EC, Wangsness PJ, Hagen DR, Etherton TD: Fetuses of lean and obese swine in late gestation: body composition, plasma hormones and muscle development. J Anim Sci 1983;57:609-620.

23 Beck B, Richy S, Archer ZA, Mercer JG: Ingestion of carbohydrate-rich supplements during gestation programs insulin and leptin resistance but not body weight gain in adult rat offspring. Front Physiol 2012;3:224.

24 Murabayashi N, Sugiyama T, Zhang L, Kamimoto Y, Umekawa T, Ma N, Sagawa N: Maternal high-fat diets cause insulin resistance through inflammatory changes in fetal adipose tissue. Eur J Obstet Gynecol Reprod Biol 2013;169:39-44.

25 Wang J, Ma H, Tong C, Zhang H, Lawlis GB, Li Y, Zang M, Ren J, Nijland MJ, Ford SP, Nathanielsz PW, Li J: Overnutrition and maternal obesity in sheep pregnancy alter the JNK-IRS-1 signaling cascades and cardiac function in the fetal heart. FASEB J 2010;24:2066-2076.

-26 Calvert JW, Lefer DJ, Gundewar S, Poston L, Coetzee WA: Developmental programming resulting from maternal obesity in mice: effects on myocardial ischaemia-reperfusion injury. Exp Physiol 2009;94:805-814.

-27 Yan X, Huang Y, Zhao JX, Long NM, Uthlaut AB, Zhu MJ, Ford SP, Nathanielsz PW, Du M: Maternal obesityimpaired insulin signaling in sheep and induced lipid accumulation and fibrosis in skeletal muscle of offspring. Biol Reprod 2011;85:172-178. 
Iozzo et al.: Developmental ORIgins of Healthy and Unhealthy AgeiNg: The Role of Maternal Obesity - Introduction to DORIAN

Zhu MJ, Han B, Tong J, Ma C, Kimzey JM, Underwood KR, Xiao Y, Hess BW, Ford SP, Nathanielsz PW, Du M: AMPactivated protein kinase signalling pathways are down regulated and skeletal muscle development impaired in fetuses of obese, over-nourished sheep. J Physiol 2008;586:2651-2664.

29 Challier JC, Basu S, Bintein T, Minium J, Hotmire K, Catalano PM, Hauguel-de Mouzon S: Obesity in pregnancy stimulates macrophage accumulation and inflammation in the placenta. Placenta 2008;29:274-281.

30 Das S, Behera MK, Misra S, Baliarsihna AK: Beta-cell function and insulin resistance in pregnancy and their relation to fetal development. Metab Syndr Relat Disord 2010;8:25-32.

-31 Catalano PM, Presley L, Minium J, Hauguel-de Mouzon S: Fetuses of obese mothers develop insulin resistance in utero. Diabetes Care 2009;32:1076-1080.

32 Catalano PM, Farrell K, Thomas A, Huston-Presley L, Mencin P, Hauguel de Mouzon SH, Amini SB: Perinatal risk factors for childhood obesity and metabolic dysregulation. Am J Clin Nutr 2009;90:1303-1313.

33 Whitaker RC: Predicting preschooler obesity at birth: the role of maternal obesity in early pregnancy. Pediatrics 2004;114:e29-36.

34 Catalano PM, Thomas AJ, Huston LP, Fung CM: Effect of maternal metabolism on fetal growth and body composition. Diabetes Care 1998;21(suppl 2):B85-90.

-35 Guiducci L, Burchielli S, Chubuchny V, Sicari R, Liistro T, Corciu AI, Pardini S, Di Cecco P, Manfredi S, Bucci M, Salvadori PA, Andreassi MG, Iozzo P: Maternal and sex dependency of insulin resistance: longitudinal PET and echocardiography study from the healthy fetus to the adult minipig. J Nucl Med 2011;52:1993-2000.

-36 Tamashiro KL: Metabolic syndrome: links to social stress and socioeconomic status. Ann N Y Acad Sci 2011; 1231:46-55.

37 Chrousos GP: Stressors, stress, and neuroendocrine integration of the adaptive response. The 1997 Hans Selye Memorial Lecture. Ann N Y Acad Sci 1998;851:311-335.

-38 Abraham NG, Brunner EJ, Eriksson JW, Robertson RP: Metabolic syndrome: psychosocial, neuroendocrine, and classical risk factors in type 2 diabetes. Ann N Y Acad Sci 2007;1113:256-275.

39 Charney DS, Manji HK: Life stress, genes, and depression: multiple pathways lead to increased risk and new opportunities for intervention. Sci STKE 2004;225:re5.

40 Dallman MF: Stress-induced obesity and the emotional nervous system. Trends Endocrinol Metab 2010;21: 159-165.

41 de Kloet ER, Joëls M, Holsboer F: Stress and the brain: from adaptation to disease. Nat Rev Neurosci 2005;6: 463-475.

42 Rosengren A, Hawken S, Ounpuu S, Sliwa K, Zubaid M, Almahmeed WA, Blackett KN, Sitthi-amorn C, Sato H, Yusuf S, for the INTERHEART investigators: Association of psychosocial risk factors with risk of acute myocardial infarction in 11119 cases and 13648 controls from 52 countries (the INTERHEART study): casecontrol study. Lancet 2004;364:953-962.

-43 Branth S, Ronquist G, Stridsberg M, Hambraeus L, Kindgren E, Olsson R, Carlander D, Arnetz B: Development of abdominal fat and incipient metabolic syndrome in young healthy men exposed to long-term stress. Nutr Metab Cardiovasc Dis 2007;17:427-435.

44 Chandola T, Brunner E, Marmot M: Chronic stress at work and the metabolic syndrome: prospective study. BMJ 2006;332:521-525.

45 Foster MT, Warne JP, Ginsberg AB, Horneman HF, Pecoraro NC, Akana SF, Dallman MF: Palatable foods, stress, and energy stores sculpt corticotropin-releasing factor, adrenocorticotropin, and corticosterone concentrations after restraint. Endocrinology 2009;150:2325-2333.

46 Cedergren MI: Maternal morbid obesity and the risk of adverse pregnancy outcome. Obstet Gynecol 2004;103: 219-224.

47 Barker DJ: The developmental origins of insulin resistance. Horm Res 2005;64(suppl 3):2-7.

48 Khan IY, Taylor PD, Dekou V, Seed PT, Lakasing L, Graham D, Dominiczak AF, Hanson MA, Poston L: Genderlinked hypertension in offspring of lard-fed pregnant rats. Hypertension 2003;41:168-175.

-49 Dunn GA, Bale TL: Maternal high-fat diet promotes body length increases and insulin insensitivity in secondgeneration mice. Endocrinology 2009;150:4999-5009.

50 Armitage JA., Khan IY, Taylor PD, Nathanielsz PW, Poston L: Developmental programming of the metabolic syndrome by maternal nutritional imbalance: how strong is the evidence from experimental models in mammals? J Physiol 2004;561:355-377.

51 Simmons R: Perinatal programming of obesity. Semin Perinatol 2008;32:371-374.

52 Sullivan EL, Smith MS., Grove KL: Perinatal exposure to high-fat diet programs energy balance, metabolism and behavior in adulthood. Neuroendocrinology 2011;93:1-8.

53 Bilbo SD, Tsang V: Enduring consequences of maternal obesity for brain inflammation and behavior of offspring. FASEB J 2010;24:2104-2115.

54 Sullivan EL, Grayson B, Takahashi D, Robertson N, Maier A, Bethea CL, Smith MS, Coleman K, Grove KL: Chronic consumption of a high-fat diet during pregnancy causes perturbations in the serotonergic system and increased anxiety-like behavior in nonhuman primate offspring. J Neurosci 2010;30:3826-3830.

55 Naef L, Srivastava L, Gratton A, Hendrickson H, Owens SM, Walker CD: Maternal high fat diet during the perinatal period alters mesocorticolimbic dopamine in the adult rat offspring: reduction in the behavioral responses to repeated amphetamine administration. Psychopharmacology (Berl) 2008;197:83-94. 
Iozzo et al.: Developmental ORIgins of Healthy and Unhealthy AgeiNg: The Role of Maternal Obesity - Introduction to DORIAN

-56 Naef L, Moquin L, Dal Bo G, Giros B, Gratton A, Walker CD: Maternal high-fat intake alters presynaptic regulation of dopamine in the nucleus accumbens and increases motivation for fat rewards in the offspring. Neuroscience 2011;176:225-236.

57 Tozuka Y, Kumon M, Wada E, Onodera M, Mochizuki H, Wada K: Maternal obesity impairs hippocampal BDNF production and spatial learning performance in young mouse offspring. Neurochem Int 2010;57:235-247.

58 Vucetic Z, Kimmel J, Totoki K, Hollenbeck E, Reyes TM: Maternal high-fat diet alters methylation and gene expression of dopamine and opioid-related genes. Endocrinology 2010;151:4756-4764.

59 Walker CD, Naef L, d'Asti E, Long H, Xu Z, Moreau A, Azeddine B: Perinatal maternal fat intake affects metabolism and hippocampal function in the offspring: a potential role for leptin. Ann N Y Acad Sci 2008;1144: 189-202.

60 Wright T, Langley-Evans SC, Voigt JP: The impact of maternal cafeteria diet on anxiety-related behaviour and exploration in the offspring. Physiol Behav 2011;103:164-172.

61 Nieuwenhuizen AG, Rutters F: The hypothalamic-pituitary-adrenal-axis in the regulation of energy balance. Physiol Behav 2008;94:169-177.

62 Bertram C, Trowern AR, Copin N, Jackson AA, Whorwood CB: The maternal diet during pregnancy programs altered expression of the glucocorticoid receptor and type 2 11beta-hydroxysteroid dehydrogenase: potential molecular mechanisms underlying the programming of hypertension in utero. Endocrinology 2001;142: 2841-2853.

63 Lindsay RS, Lindsay RM, Waddell BJ, Seckl JR: Prenatal glucocorticoid exposure leads to offspring hyperglycaemia in the rat: studies with the 11 beta-hydroxysteroid dehydrogenase inhibitor carbenoxolone. Diabetologia 1996;39:1299-1305.

64 Nyirenda MJ, Lindsay RS, Kenyon CJ, Burchell A, Seckl JR: Glucocorticoid exposure in late gestation permanently programs rat hepatic phosphoenolpyruvate carboxykinase and glucocorticoid receptor expression and causes glucose intolerance in adult offspring. J Clin Invest 1998;101:2174-2181.

65 Tamashiro KL, Terrillion CE, Hyun J, Koenig JI, Moran TH: Prenatal stress or high-fat diet increases susceptibility to diet-induced obesity in rat offspring. Diabetes 2009;58:1116-1125.

66 Mueller BR, Bale TL: Impact of prenatal stress on long term body weight is dependent on timing and maternal sensitivity. Physiol Behav 2006;88:605-614.

67 Trottier G, Koski KG, Brun T, Toufexis DJ, Richard D, Walker CD: Increased fat intake during lactation modifies hypothalamic-pituitary-adrenal responsiveness in developing rat pups: a possible role for leptin. Endocrinology 1998;139:3704-3711.

-68 Schmidt MV, Levine S, Alam S, Harbich D, Sterlemann V, Ganea K, de Kloet ER, Holsboer F, Müller MB: Metabolic signals modulate hypothalamic-pituitary-adrenal axis activation during maternal separation of the neonatal mouse. J Neuroendocrinol 2006;18:865-874.

69 Gallagher P, Watson S, Smith MS, Young AH, Ferrier IN: Plasma cortisol-dehydroepiandrosterone (DHEA) ratios in schizophrenia and bipolar disorder. Schizophr Res 2007;90:258-265.

70 Holsboer F: The corticosteroid receptor hypothesis of depression. Neuropsychopharmacology 2000;23:477-501.

71 Holsboer F, Ising M: Stress hormone regulation: biological role and translation into therapy. Annu Rev Psychol 2010;61:81-109, C1-11.

72 Faith MS, Matz PE, Jorge MA: Obesity-depression associations in the population. J Psychosom Res 2002;53: 935-942.

-73 Viinamäki H, Heiskanen T, Lehto SM, Niskanen L, Koivumaa-Honkanen H, Tolmunen T, Honkalampi K, Saharinen T, Haatainen K, Hintikka J: Association of depressive symptoms and metabolic syndrome in men. Acta Psychiatr Scand 2009;120:23-29.

-74 Räikkönen K, Matthews KA, Kuller LH: The relationship between psychological risk attributes and the metabolic syndrome in healthy women: antecedent or consequence? Metabolism 2002;51:1573-1577.

75 Skilton MR, Moulin P, Terra JL, Bonnet F: Associations between anxiety, depression, and the metabolic syndrome. Biol Psychiatry 2007;62:1251-1257.

-76 Toker S, Shirom A, Melamed S: Depression and the metabolic syndrome: gender-dependent associations. Depress Anxiety 2008;25:661-669.

77 Barden N: Modulation of glucocorticoid receptor gene expression by antidepressant drugs. Pharmacopsychiatry 1996;29:12-22.

-78 Holsboer F, Barden N: Antidepressants and hypothalamic-pituitary-adrenocortical regulation. Endocr Rev 1996;17:187-205.

79 Rosmond R, Björntorp P: The role of antidepressants in the treatment of abdominal obesity. Med Hypotheses 2000;54:990-994.

-80 Edwards CR, Benediktsson R, Lindsay RS, Seckl JR: Dysfunction of placental glucocorticoid barrier: link between fetal environment and adult hypertension? Lancet 1993;341:355-357.

81 Benediktsson R, Lindsay RS, Noble J, Seckl JR, Edwards CR: Glucocorticoid exposure in utero: new model for adult hypertension. Lancet 1993;341:339-341.

82 Stewart PM, Whorwood CB, Mason JI: Type 211 beta-hydroxysteroid dehydrogenase in foetal and adult life. J Steroid Biochem Mol Biol 1995;55:465-471.

83 Murphy VE, Zakar T, Smith R, Giles WB, Gibson PG, Clifton VL: Reduced 11beta-hydroxysteroid dehydrogenase type 2 activity is associated with decreased birth weight centile in pregnancies complicated by asthma. J Clin Endocrinol Metab 2002;87:1660-1668. 
84 Kajantie E, Dunkel L, Turpeinen U, Stenman UH, Wood PJ, Nuutila M, Andersson S: Placental 11 beta-hydroxysteroid dehydrogenase-2 and fetal cortisol/cortisone shuttle in small preterm infants. J Clin Endocrinol Metab 2003;88:493-500.

85 Aufdenblatten M, Baumann M, Raio L, Dick B, Frey BM, Schneider H, Surbek D, Hocher B, Mohaupt MG: Prematurity is related to high placental cortisol in preeclampsia. Pediatr Res 2009;65:198-202.

86 Mune T, Rogerson FM, Nikkilä H, Agarwal AK, White PC: Human hypertension caused by mutations in the kidney isozyme of 11 beta-hydroxysteroid dehydrogenase. Nat Genet 1995;10:394-399.

87 Lindsay RS, Lindsay RM, Edwards CR, Seckl JR: Inhibition of 11-beta-hydroxysteroid dehydrogenase in pregnant rats and the programming of blood pressure in the offspring. Hypertension 1996;27:1200-1204.

88 Dave-Sharma S, Wilson RC, Harbison MD, Newfield R, Azar MR, Krozowski ZS, Funder JW, Shackleton CH, Bradlow HL, Wei JQ, Hertecant J, Moran A, Neiberger RE, Balfe JW, Fattah A, Daneman D, Akkurt HI, De Santis C, New MI: Examination of genotype and phenotype relationships in 14 patients with apparent mineralocorticoid excess. J Clin Endocrinol Metab 1998;83:2244-2254.

89 Smith JT, Waddell BJ: Increased fetal glucocorticoid exposure delays puberty onset in postnatal life. Endocrinology 2000;141:2422-2428.

90 Welberg LA, Seckl JR, Holmes MC: Inhibition of 11beta-hydroxysteroid dehydrogenase, the foeto-placental barrier to maternal glucocorticoids, permanently programs amygdala GR mRNA expression and anxiety-like behaviour in the offspring. Eur J Neurosci 2000;12:1047-1054.

91 O’Regan D, Kenyon CJ, Seckl JR, Holmes MC: Glucocorticoid exposure in late gestation in the rat permanently programs gender-specific differences in adult cardiovascular and metabolic physiology. Am J Physiol Endocrinol Metab 2004;287:E863-870.

92 Holmes MC, Abrahamsen CT, French KL, Paterson JM, Mullins JJ, Seckl JR: The mother or the fetus? 11betahydroxysteroid dehydrogenase type 2 null mice provide evidence for direct fetal programming of behavior by endogenous glucocorticoids. J Neurosci 2006;26:3840-3844.

93 Wyrwoll CS, Mark PJ, Mori TA, Puddey IB, Waddell BJ: Prevention of programmed hyperleptinemia and hypertension by postnatal dietary omega-3 fatty acids. Endocrinology 2006;147:599-606.

$\$ 94$ de Vries A, Holmes MC, Heijnis A, Seier JV, Heerden J, Louw J, Wolfe-Coote S, Meaney MJ, Levitt NS, Seckl JR: Prenatal dexamethasone exposure induces changes in nonhuman primate offspring cardiometabolic and hypothalamic-pituitary-adrenal axis function. J Clin Invest 2007;117:1058-1067.

$\$ 95$ Wyrwoll CS, Mark PJ, Waddell BJ: Developmental programming of renal glucocorticoid sensitivity and the renin-angiotensin system. Hypertension 2007;50:579-584.

96 Newnham JP, Jobe AH: Should we be prescribing repeated courses of antenatal corticosteroids? Semin Fetal Neonatal Med 2009;14:157-163.

97 Nyirenda MJ, Carter R, Tang JI, de Vries A, Schlumbohm C, Hillier SG, Streit F, Oellerich M, Armstrong VW, Fuchs E, Seckl JR: Prenatal programming of metabolic syndrome in the common marmoset is associated with increased expression of 11beta-hydroxysteroid dehydrogenase type 1. Diabetes 2009;58:2873-2879.

$\$ 98$ Wyrwoll CS, Seckl JR, Holmes MC: Altered placental function of 11beta-hydroxysteroid dehydrogenase 2 knockout mice. Endocrinology 2009;150:1287-1293.

99 O’Donnell KJ, Bugge Jensen A, Freeman L, Khalife N, O'Connor TG, Glover V: Maternal prenatal anxiety and downregulation of placental 11ß-HSD2. Psychoneuroendocrinology 2012;37:818-826.

100 Kitanaka S, Tanae A, Hibi I: Apparent mineralocorticoid excess due to 11 beta-hydroxysteroid dehydrogenase deficiency: a possible cause of intrauterine growth retardation. Clin Endocrinol (Oxf) 1996;44:353-359.

101 Räikkönen K, Pesonen AK, Heinonen K, Lahti J, Komsi N, Eriksson JG, Seckl JR, Järvenpää AL, Strandberg TE: Maternal licorice consumption and detrimental cognitive and psychiatric outcomes in children. Am J Epidemiol 2009;170:1137-1146.

102 Räikkönen K, Seckl JR, Heinonen K, Pyhälä R, Feldt K, Jones A, Pesonen AK, Phillips DI, Lahti J, Järvenpää AL, Eriksson JG, Matthews KA, Strandberg TE, Kajantie E: Maternal prenatal licorice consumption alters hypothalamic-pituitary-adrenocortical axis function in children. Psychoneuroendocrinology 2010;35:1587-1593.

103 Welberg LA, Seckl JR, Holmes MC: Prenatal glucocorticoid programming of brain corticosteroid receptors and corticotrophin-releasing hormone: possible implications for behaviour. Neuroscience 2001;104:71-79.

104 Nagano M, Ozawa H, Suzuki H: Prenatal dexamethasone exposure affects anxiety-like behaviour and neuroendocrine systems in an age-dependent manner. Neurosci Res 2008;60:364-371.

105 Weaver IC, Cervoni N, Champagne FA, D’Alessio AC, Sharma S, Seckl JR, Dymov S, Szyf M, Meaney MJ: Epigenetic programming by maternal behavior. Nat Neurosci 2004;7:847-854.

106 Drake AJ, Walker BR, Seckl JR: Intergenerational consequences of fetal programming by in utero exposure to glucocorticoids in rats. Am J Physiol Regul Integr Comp Physiol 2005;288:R34-38.

107 Nyirenda MJ, Dean S, Lyons V, Chapman KE, Seckl JR: Prenatal programming of hepatocyte nuclear factor 4alpha in the rat: A key mechanism in the 'foetal origins of hyperglycaemia'? Diabetologia 2006;49:14121420.

108 Seckl JR: Glucocorticoids, developmental 'programming' and the risk of affective dysfunction. Prog Brain Res 2008;167:17-34

109 Drake AJ, Liu L, Kerrigan D, Meehan RR, Seckl JR: Multigenerational programming in the glucocorticoid programmed rat is associated with generation-specific and parent of origin effects. Epigenetics 2011;6:13341343. 
Iozzo et al.: Developmental ORIgins of Healthy and Unhealthy AgeiNg: The Role of Maternal Obesity - Introduction to DORIAN

110 Sandovici I, Smith NH, Nitert MD, Ackers-Johnson M, Uribe-Lewis S, Ito Y, Jones RH, Marquez VE, Cairns W, Tadayyon M, O’Neill LP, Murrell A, Ling C, Constância M, Ozanne SE: Maternal diet and aging alter the epigenetic control of a promoter-enhancer interaction at the Hnf $4 a$ gene in rat pancreatic islets. Proc Natl Acad Sci U S A 2011;108:5449-5454.

111 Weaver IC, Szyf M, Meaney MJ: From maternal care to gene expression: DNA methylation and the maternal programming of stress responses. Endocr Res 2002;28:699.

112 Alikhani-Koopaei R, Fouladkou F, Frey FJ, Frey BM: Epigenetic regulation of 11 beta-hydroxysteroid dehydrogenase type 2 expression. J Clin Invest 2004;114:1146-1157.

113 Mueller BR, Bale TL: Sex-specific programming of offspring emotionality after stress early in pregnancy. J Neurosci 2008;28:9055-9065.

-114 Murgatroyd C, Patchev AV, Wu Y, Micale V, Bockmühl Y, Fischer D, Holsboer F, Wotjak CT, Almeida OF, Spengler D: Dynamic DNA methylation programs persistent adverse effects of early-life stress. Nat Neurosci 2009;12: 1559-1566.

115 Waterland RA, Jirtle RL: Transposable elements: targets for early nutritional effects on epigenetic gene regulation. Mol Cell Biol 2003;23:5293-5300.

116 Wyrwoll CS, Holmes MC: Prenatal excess glucocorticoid exposure and adult affective disorders: a role for serotonergic and catecholamine pathways. Neuroendocrinology 2012;95:47-55.

117 Kotelevtsev Y, Brown RW, Fleming S, Kenyon C, Edwards CR, Seckl JR, Mullins JJ: Hypertension in mice lacking 11beta-hydroxysteroid dehydrogenase type 2. J Clin Invest 1999;103:683-689.

118 Jensen E, Wood CE, Keller-Wood M: Reduction of maternal adrenal steroids results in increased VEGF protein without increased eNOS in the ovine placenta. Placenta 2007;28:658-667.

119 Waddell BJ, Hisheh S, Dharmarajan AM, Burton PJ: Apoptosis in rat placenta is zone-dependent and stimulated by glucocorticoids. Biol Reprod 2000;63:1913-1917.

120 Whorwood CB, Firth KM, Budge H, Symonds ME: Maternal undernutrition during early to midgestation programs tissue-specific alterations in the expression of the glucocorticoid receptor, 11ß-hydroxysteroid dehydrogenase isoforms, and type 1 angiotensin II receptor in neonatal sheep. Endocrinology 2001;142: 2854-2864.

121 Yehuda R, Bierer LM, Andrew R, Schmeidler J, Seckl JR: Enduring effects of severe developmental adversity, including nutritional deprivation, on cortisol metabolism in aging Holocaust survivors. J Psychiatr Res 2009; 43:877-883

122 Lesage J, Blondeau B, Grino M, Bréant B, Dupouy JP: Maternal undernutrition during late gestation induces fetal overexposure to glucocorticoids and intrauterine growth retardation, and disturbs the hypothalamopituitary adrenal axis in the newborn rat. Endocrinology 2001;142:1692-1702.

123 Guzmán C, Cabrera R, Cárdenas M, Larrea F, Nathanielsz PW, Zambrano E: Protein restriction during fetal and neonatal development in the rat alters reproductive function and accelerates reproductive ageing in female progeny. J Physiol 2006;572:97-108.

124 Langley-Evans SC, Phillips GJ, Benediktsson R, Gardner DS, Edwards CRW, Jackson AA, Seckl JR: Protein intake in pregnancy, placental glucocorticoid metabolism and the programming of hypertension in the rat. Placenta 1996;17:169-172.

125 Stocker C, O’Dowd J, Morton NM, Wargent E, Sennitt MV, Hislop D, Glund S, Seckl JR, Arch JR, Cawthorne MA: Modulation of susceptibility to weight gain and insulin resistance in low birthweight rats by treatment of their mothers with leptin during pregnancy and lactation. Int J Obes Relat Metab Disord 2004;28:129-136.

126 LaBorde JB, Hansen DK, Young JF, Sheehan DM, Holson RR: Prenatal dexamethasone exposure in rats: effects of dose, age at exposure, and drug-induced hypophagia on malformations and fetal organ weights. Fundam Appl Toxicol 1992;19:545-554.

127 Cottrell EC, Holmes MC, Livingstone DE, Kenyon CJ, Seckl JR: Reconciling the nutritional and glucocorticoid hypotheses of fetal programming. FASEB J 2012;26:1866-1874.

128 Khorram NM, Magee TR, Wang C, Desai M, Ross M, Khorram O: Maternal undernutrition programs offspring adrenal expression of steroidogenic enzymes. Reprod Sci 2011;18:931-940.

129 Shiell AW, Campbell-Brown M, Haselden S, Robinson S, Godfrey KM, Barker DJ: High-meat, low-carbohydrate diet in pregnancy: relation to adult blood pressure in the offspring. Hypertension 2001;38:1282-1288.

130 Herrick K, Phillips DI, Haselden S, Shiell AW, Campbell-Brown M, Godfrey KM: Maternal consumption of a highmeat, low-carbohydrate diet in late pregnancy: relation to adult cortisol concentrations in the offspring. J Clin Endocrinol Metab 2003;88:3554-3560.

131 Reynolds RM, Godfrey KM, Barker M, Osmond C, Phillips DI: Stress responsiveness in adult life: influence of mother's diet in late pregnancy. J Clin Endocrinol Metab 2007;92:2208-2210.

132 Drake AJ, McPherson RC, Godfrey KM, Cooper C, Lillycrop KA, Hanson MA, Meehan RR, Seckl JR, Reynolds RM: An unbalanced maternal diet in pregnancy associates with offspring epigenetic changes in genes controlling glucocorticoid action and foetal growth. Clin Endocrinol (Oxf) 2012;77:808-815.

-133 Samuelsson AM, Matthews PA, Argenton M, Christie MR, McConnell JM, Jansen EH, Piersma AH, Ozanne SE, Twinn DF, Remacle C, Rowlerson A, Poston L, Taylor PD: Diet-induced obesity in female mice leads to offspring hyperphagia, adiposity, hypertension, and insulin resistance: a novel murine model of developmental programming. Hypertension 2008;51:383-392.

134 Drake AJ, Reynolds RM: Impact of maternal obesity on offspring obesity and cardiometabolic disease risk. Reproduction 2010;140:387-398. 
Iozzo et al.: Developmental ORIgins of Healthy and Unhealthy AgeiNg: The Role of Maternal Obesity - Introduction to DORIAN

135 Berniakovich I, Trinei M, Stendardo M, Migliaccio E, Minucci S, Bernardi P, Pelicci PG, Giorgio M: p66Shcgenerated oxidative signal promotes fat accumulation. J Biol Chem 2008;283:34283-34293.

136 Berry A, Amrein I, Nötzli S, Lazic SE, Bellisario V, Giorgio M, Pelicci PG, Alleva E, Lipp HP, Cirulli F: Sustained hippocampal neurogenesis in females is amplified in P66(Shc-/-) mice: An animal model of healthy aging. Hippocampus 2012;22:2249-2259.

137 Berry A, Capone F, Giorgio M, Pelicci PG, de Kloet ER, Alleva E, Minghetti L, Cirulli F: Deletion of the life span determinant p66Shc prevents age-dependent increases in emotionality and pain sensitivity in mice. Exp Gerontol 2007; 42:37-45.

138 Berry A, Carnevale D, Giorgio M, Pelicci PG, de Kloet ER, Alleva E, Minghetti L, Cirulli F: Greater resistance to inflammation at adulthood could contribute to extended life span of p66(Shc-/-) mice. Exp Gerontol 2010;45: 343-350.

139 Berry A, Greco A, Giorgio M, Pelicci PG, de Kloet R, Alleva E, Minghetti L, Cirulli F: Deletion of the lifespan determinant p66(Shc) improves performance in a spatial memory task, decreases levels of oxidative stress markers in the hippocampus and increases levels of the neurotrophin BDNF in adult mice. Exp Gerontol 2008;43:200-208.

140 Giorgio M, Berry A, Berniakovich I, Poletaeva I, Trinei M, Stendardo M, Hagopian K, Ramsey JJ, Cortopassi G, Migliaccio E, Nötzli S, Amrein I, Lipp HP, Cirulli F, Pelicci PG: The p66Shc knocked out mice are short lived under natural condition. Aging Cell 2012;11:162-168.

141 Migliaccio E, Giorgio M, Mele S, Pelicci G, Reboldi P, Pandolfi PP, Lanfrancone L, Pelicci PG: The p66shc adaptor protein controls oxidative stress response and life span in mammals. Nature 1999;402:309-313.

142 Bayram B, Nikolai S, Huebbe P, Ozcelik B, Grimm S, Grune T, Frank J, Rimbach G: Biomarkers of oxidative stress, antioxidant defence and inflammation are altered in the senescence-accelerated mouse prone 8. Age (Dordr) 2013;35:1205-1217.

143 Holzenberger M, Dupont J, Ducos B, Leneuve P, Géloën A, Even PC, Cervera P, Le Bouc Y: IGF-1 receptor regulates lifespan and resistance to oxidative stress in mice. Nature 2003;421:182-187.

144 Kenyon C, Chang J, Gensch E, Rudner A, Tabtiang R: A C. elegans mutant that lives twice as long as wild type. Nature 1993;366:461-464.

145 Kimura KD, Tissenbaum HA, Liu Y, Ruvkun G: daf-2, an insulin receptor-like gene that regulates longevity and diapause in Caenorhabditis elegans. Science 1997;277:942-946.

146 Longo VD, Finch CE: Evolutionary medicine: from dwarf model systems to healthy centenarians? Science 2003;299:1342-1346.

147 Tatar M, Kopelman A, Epstein D, Tu MP, Yin CM, Garofalo RS: A mutant Drosophila insulin receptor homolog that extends life-span and impairs neuroendocrine function. Science 2001;292:107-110.

148 Treiber N, Maity P, Singh K, Kohn M, Keist AF, Ferchiu F, Sante L, Frese S, Bloch W, Kreppel F, Kochanek S, Sindrilaru A, Iben S, Högel J, Ohnmacht M, Claes LE, Ignatius A, Chung JH, Lee MJ, Kamenisch Y, Berneburg M, Nikolaus T, Braunstein K, Sperfeld AD, Ludolph AC, Briviba K, Wlaschek M, Florin L, Angel P, ScharffetterKochanek K: Accelerated aging phenotype in mice with conditional deficiency for mitochondrial superoxide dismutase in the connective tissue. Aging Cell 2011;10:239-254.

149 Barzilai N, Huffman DM, Muzumdar RH, Bartke A: The critical role of metabolic pathways in aging. Diabetes 2012;61:1315-1322.

150 Folsom AR, Kaye SA, Sellers TA, Hong CP, Cerhan JR, Potter JD, Prineas RJ: Body fat distribution and 5-year risk of death in older women. JAMA 1993;269:483-487.

151 Morley JE: Diabetes and aging: epidemiologic overview. Clin Geriatr Med 2008;24:395-405.

152 Sepe A, Tchkonia T, Thomou T, Zamboni M, Kirkland JL: Aging and regional differences in fat cell progenitors - a mini-review. Gerontology 2011;57:66-75.

153 Haffner S, Taegtmeyer H: Epidemic obesity and the metabolic syndrome. Circulation 2003;108:1541-1545.

154 Fadini GP, Ceolotto G, Pagnin E, de Kreutzenberg S, Avogaro A: At the crossroads of longevity and metabolism: the metabolic syndrome and lifespan determinant pathways. Aging Cell 2011;10:10-17.

155 Engum A: The role of depression and anxiety in onset of diabetes in a large population-based study.JPsychosom Res 2007;62:31-38.

156 Goldbacher EM, Bromberger J, Matthews KA: Lifetime history of major depression predicts the development of the metabolic syndrome in middle-aged women. Psychosom Med 2009;71:266-272.

157 Muller M, van Raamt F, Visseren FL, Kalmijn S, Geerlings MI, Mali WP, van der Graaf Y: Metabolic syndrome and cognition in patients with manifest atherosclerotic disease: the SMART study. Neuroepidemiology 2010; 34:83-89.

158 Raffaitin C, Féart C, Le Goff M, Amieva H, Helmer C, Akbaraly TN, Tzourio C, Gin H, Barberger-Gateau P: Metabolic syndrome and cognitive decline in French elders: the Three-City Study. Neurology 2011;76:518-525.

159 van Reedt Dortland AK, Giltay EJ, van Veen T, Zitman FG, Penninx BW: Metabolic syndrome abnormalities are associated with severity of anxiety and depression and with tricyclic antidepressant use. Acta Psychiatr Scand 2010;122:30-39.

160 Zeugmann S, Quante A, Heuser I, Schwarzer R, Anghelescu I: Inflammatory biomarkers in 70 depressed inpatients with and without the metabolic syndrome. J Clin Psychiatry 2010;71:1007-1016.

161 Bandyopadhyay D, Medrano EE: The emerging role of epigenetics in cellular and organismal aging. Exp Gerontol 2003;38:1299-1307.

162 Park LK, Friso S, Choi SW: Nutritional influences on epigenetics and age-related disease. Proc Nutr Soc 2012; 71:75-83. 
Iozzo et al.: Developmental ORIgins of Healthy and Unhealthy AgeiNg: The Role of Maternal Obesity - Introduction to DORIAN

163 Li KK, Li F, Li QS, Yang K, Jin B: DNA methylation as a target of epigenetic therapeutics in cancer. Anticancer Agents Med Chem 2013;13:242-247.

164 Wu G, Bazer FW, Cudd TA, Meininger CJ, Spencer TE: Maternal nutrition and fetal development. J Nutr 2004; 134:2169-2172.

165 Lillycrop KA, Phillips ES, Jackson AA, Hanson MA, Burdge GC: Dietary protein restriction of pregnant rats induces and folic acid supplementation prevents epigenetic modification of hepatic gene expression in the offspring. J Nutr 2005;135:1382-1386.

166 Lillycrop KA, Phillips ES, Torrens C, Hanson MA, Jackson AA, Burdge GC: Feeding pregnant rats a proteinrestricted diet persistently alters the methylation of specific cytosines in the hepatic PPAR alpha promoter of the offspring. Br J Nutr 2008;100:278-282.

167 Gluckman PD, Hanson MA, Cooper C, Thornburg KL: Effect of in utero and early-life conditions on adult health and disease. N Engl J Med 2008;359:61-73.

168 Godfrey KM, Sheppard A, Gluckman PD, Lillycrop KA, Burdge GC, McLean C, Rodford J, Slater-Jefferies JL, Garratt E, Crozier SR, Emerald BS, Gale CR, Inskip HM, Cooper C, Hanson MA: Epigenetic gene promoter methylation at birth is associated with child's later adiposity. Diabetes 2011;60:1528-1534.

169 Portela A, Esteller M: Epigenetic modifications and human disease. Nat Biotechnol 2010;28:1057-1068.

170 Meaburn E, Schulz R: Next generation sequencing in epigenetics: insights and challenges. Semin Cell Dev Biol 2012;23:192-199.

171 Heyn H, Vidal E, Sayols S, Sanchez-Mut JV, Moran S, Medina I, Sandoval J, Simó-Riudalbas L, Szczesna K, Huertas D, Gatto S, Matarazzo MR, Dopazo J, Esteller M: Whole-genome bisulfite DNA sequencing of a DNMT3B mutant patient. Epigenetics 2012;7:542-550.

$\checkmark 172$ Serre D, Lee BH, Ting AH: MBD-isolated genome sequencing provides a high-throughput and comprehensive survey of DNA methylation in the human genome. Nucleic Acids Res 2010;38:391-399.

$\checkmark 173$ Li H, Durbin R: Fast and accurate short read alignment with Burrows-Wheeler transform. Bioinformatics 2009;25:1754-1760.

174 Huang J, Renault V, Sengenès J, Touleimat N, Michel S, Lathrop M, Tost J: MeQA: a pipeline for MeDIP-seq data quality assessment and analysis. Bioinformatics 2012;28:587-588.

175 Bailey TL, Williams N, Misleh C, Li WW: MEME: discovering and analyzing DNA and protein sequence motifs. Nucleic Acids Res 2006;34:W369-373.

176 Gorska E, Popko K, Stelmaszczyk-Emmel A, Ciepiela 0, Kucharska A, Wasik M: Leptin receptors. Eur J Med Res 2010;15(suppl 2):50-54.

177 Price LH, Kao HT, Burgers DE, Carpenter LL, Tyrka AR: Telomeres and early-life stress: an overview. Biol Psychiatry 2013;73:15-23.

178 Song Z, von Figura G, Liu Y, Kraus JM, Torrice C, Dillon P, Rudolph-Watabe M, Ju Z, Kestler HA, Sanoff H, Lenhard Rudolph K: Lifestyle impacts on the aging-associated expression of biomarkers of DNA damage and telomere dysfunction in human blood. Aging Cell 2010;9:607-615.

179 Valdes AM, Andrew T, Gardner JP, Kimura M, Oelsner E, Cherkas LF, Aviv A, Spector TD: Obesity, cigarette smoking, and telomere length in women. Lancet 2005;366:662-664.

180 Furukawa S, Fujita T, Shimabukuro M, Iwaki M, Yamada Y, Nakajima Y, Nakayama O, Makishima M, Matsuda $\mathrm{M}$, Shimomura I: Increased oxidative stress in obesity and its impact on metabolic syndrome. J Clin Invest 2004;114:1752-1761.

181 Monickaraj F, Gokulakrishnan K, Prabu P, Sathishkumar C, Anjana RM, Rajkumar JS, Mohan V, Balasubramanyam M: Convergence of adipocyte hypertrophy, telomere shortening and hypoadiponectinemia in obese subjects and in patients with type 2 diabetes. Clin Biochem 2012;45:1432-1438.

182 Njajou OT, Cawthon RM, Blackburn EH, Harris TB, Li R, Sanders JL, Newman AB, Nalls M, Cummings SR, Hsueh WC: Shorter telomeres are associated with obesity and weight gain in the elderly. Int J Obes (Lond) 2012;36: 1176-1179.

183 Cassidy A, De Vivo I, Liu Y, Han J, Prescott J, Hunter DJ, Rimm EB: Associations between diet, lifestyle factors, and telomere length in women. Am J Clin Nutr 2010;91:1273-1280.

184 Jennings BJ, Ozanne SE, Dorling MW, Hales CN: Early growth determines longevity in male rats and may be related to telomere shortening in the kidney. FEBS Lett 1999;448:4-8.

185 Epel ES, Blackburn EH, Lin J, Dhabhar FS, Adler NE, Morrow JD, Cawthon RM: Accelerated telomere shortening in response to life stress. Proc Natl Acad Sci U S A 2004;101:17312-17315.

186 Buxton JL, Walters RG, Visvikis-Siest S, Meyre D, Froguel P, Blakemore AL: Childhood obesity is associated with shorter leukocyte telomere length. J Clin Endocrinol Metab 2011;96:1500-1505.

187 Zannolli R, Mohn A, Buoni S, Pietrobelli A, Messina M, Chiarelli F, Miracco C: Telomere length and obesity. Acta Paediatr 2008;97:952-954.

188 Al-Attas OS, Al-Daghri N, Bamakhramah A, Shaun Sabico S, McTernan P, Huang TT: Telomere length in relation to insulin resistance, inflammation and obesity among Arab youth. Acta Paediatr 2010;99:896-899.

189 Entringer S, Buss C, Wadhwa PD: Prenatal stress, telomere biology, and fetal programming of health and disease risk. Sci Signal 2012;5:pt12.

190 Tarry-Adkins JL, Chen JH, Smith NS, Jones RH, Cherif H, Ozanne SE: Poor maternal nutrition followed by accelerated postnatal growth leads to telomere shortening and increased markers of cell senescence in rat islets. FASEB J 2009;23:1521-1528. 
Iozzo et al.: Developmental ORIgins of Healthy and Unhealthy AgeiNg: The Role of Maternal Obesity - Introduction to DORIAN

191 Tarry-Adkins JL, Martin-Gronert MS, Chen JH, Cripps RL, Ozanne SE: Maternal diet influences DNA damage, aortic telomere length, oxidative stress, and antioxidant defense capacity in rats. FASEB J 2008;22:20372044.

192 Haussmann MF, Longenecker AS, Marchetto NM, Juliano SA, Bowden RM: Embryonic exposure to corticosterone modifies the juvenile stress response, oxidative stress and telomere length. Proc Biol Sci 2012;279: 1447-1456.

193 Entringer S, Epel ES, Kumsta R, Lin J, Hellhammer DH, Blackburn EH, Wüst S, Wadhwa PD: Stress exposure in intrauterine life is associated with shorter telomere length in young adulthood. Proc Natl Acad Sci U S A 2011; 108:E513-518.

194 Okuda K, Bardeguez A, Gardner JP, Rodriguez P, Ganesh V, Kimura M, Skurnick J, Awad G, Aviv A: Telomere length in the newborn. Pediatr Res 2002;52:377-381.

195 Davy P, Nagata M, Bullard P, Fogelson NS, Allsopp R: Fetal growth restriction is associated with accelerated telomere shortening and increased expression of cell senescence markers in the placenta. Placenta 2009;30: 539-542.

196 Biron-Shental T, Kidron D, Sukenik-Halevy R, Goldberg-Bittman L, Sharony R, Fejgin MD, Amiel A: TERC telomerase subunit gene copy number in placentas from pregnancies complicated with intrauterine growth restriction. Early Hum Dev 2011;87:73-75.

197 Cross JA, Temple RC, Hughes JC, Dozio NC, Brennan C, Stanley K, Murphy HR, Fowler D, Hughes DA, Sampson MJ: Cord blood telomere length, telomerase activity and inflammatory markers in pregnancies in women with diabetes or gestational diabetes. Diabet Med 2010;27:1264-1270.

198 Sahin E, DePinho RA: Axis of ageing: telomeres, p53 and mitochondria. Nat Rev Mol Cell Biol 2012;13:397404.

199 Lin PH, Lee SH, Su CP, Wei YH: Oxidative damage to mitochondrial DNA in atrial muscle of patients with atrial fibrillation. Free Radic Biol Med 2003;35:1310-1318.

200 Corral-Debrinski M, Shoffner JM, Lott MT, Wallace DC: Association of mitochondrial DNA damage with aging and coronary atherosclerotic heart disease. Mutat Res 1992;275:169-180.

201 Botto N, Berti S, Manfredi S, Al-Jabri A, Federici C, Clerico A, Ciofini E, Biagini A, Andreassi MG: Detection of mtDNA with $4977 \mathrm{bp}$ deletion in blood cells and atherosclerotic lesions of patients with coronary artery disease. Mutat Res 2005;570:81-88. 